\title{
Snail Switches 5-FU-induced Apoptosis to Necrosis through Akt/PKB Activation and p53 Down-regulation
}

\author{
Su Yeon Lee', Hyun Min Jeon', Min Kyung Ju', Cho Hee Kim ${ }^{1+}$, Euil-kyong Jeong ${ }^{1}$, Hye Gyeong \\ Park $^{2} *$ and Ho Sung Kang ${ }^{1} *$
}

${ }^{1}$ Department of Molecular Biology, College of Natural Sciences, ${ }^{2}$ Nanobiotechnology Center, Pusan National University, Pusan 609-735, Korea

Received July 9, 2012 /Revised August 16, 2012 /Accepted August 16, 2012

\begin{abstract}
Snail is a zinc finger transcription factor that induces epithelial-to-mesenchymal transition (EMT), which promotes tumor invasion and metastasis by repressing E-cadherin expression. In addition, Snail restricts the cellular apoptotic response to apoptotic stimuli or survival factor withdrawal; however, its molecular mechanism remains largely unknown. In this study, we have investigated the mechanism underlying Snail-mediated chemoresistance to 5-fluorouracil (5-FU), one of the most widely used anti-cancer drugs. When Snail was overexpressed by doxycycline (DOX) in MCF-7 \#5 cells, it inhibited 5-FU-induced apoptotic cell death and switched the cell death mode to necrosis. Snail expression, either by DOX treatment in MCF-7 \#5 cells or by the transfection of Snail expression vectors pCR3.1-Snail-Flg, phosphorylation-resistant pCR3.1-S104, and 107A Snail-Flg in MCF-7 cells specifically induced PTEN down-regulation/inactivation and Akt/PKB activation, without affecting ERK1/2 activity. In addition, Snail prominently suppressed 5-FU-induced increases in p53 levels. These findings demonstrate that Snail switches 5-FU-induced apoptosis to necrosis through the activation of $\mathrm{Akt} / \mathrm{PKB}$ and the down-regulation of p53 levels.
\end{abstract}

Key words : Snail, 5-fluorouracil (5-FU), apoptosis/necrosis, Akt/PKB, p53

\section{Introduction}

Snail is induced by many kinds of tumor stimulating cytokines, such as transforming growth factor (TGF) $\beta$ and Wnt, and triggers epithelial-to-mesenchymal transition (EMT) that contributes to tumor cell invasion and metastases, by directly repressing the transcription of epithelial cell markers, such as E-cadherin, occludin, and claudins [13,14]. Snail protein has been observed in the invasive tumor including breast and colorectal cancers and hepatocellular carcinomas, spreading toward the outer regions. Snail expression is correlated not only with invasive potential, but also with the development of resistance to pro-apoptotic stimuli including radiation and anti-cancer drugs $[4,7,20,23]$. The tumor suppressor p53 and an Akt/PKB negative regulator PTEN phosphatase have been implicated in the Snail-mediated resistance to apoptosis [2,5]; however, its molecular mechanism

†Present author: DNA Identification Center, National Forensic Service, Seoul 158-707, Korea

*Corresponding author

Tel : +82-51-510-2275, Fax : +82-51-513-9258

E-mail : hspkang@pusan.ac.kr

*Corresponding author

E-mail: phkay@lycos.co.kr remains largely unknown. Because Snail endows epithelial cells with anti-apoptotic activities as well as migratory abilities, aberrant expression of Snail promotes tumorigenesis, resulting in poor prognosis.

5-Fluorouracil (5-FU) is a pyrimidine analogue widely used in the treatment of breast, colon, rectum, pancreas, stomach, and skin cancers $[11,26]$. It interferes with nucleoside metabolism and can be incorporated into RNA and DNA, causing cytotoxicity and cell death. 5-FU is known to trigger apoptosis by inducing the tumor suppressor p53, which stimulates the expression of pro-apoptotic Bax, while suppressing that of anti-apoptotic Bcl-2. The sensitivity of cancer cells to 5-FU is influenced by diverse molecular mechanisms, including prosurvival signaling pathways such as the Ser/Thr kinases Akt/protein kinase B (PKB) and ERK1/2 [1,17,21,22,24].

In this study, we investigated the mechanism underlying Snail-mediated inhibition of apoptosis induced in response to 5-FU. We show that Snail inhibits 5-FU-induced apoptotic cell death and switches the cell death mode to necrosis, in which the prosurvival kinase Akt/protein kinase B (PKB) activation and p53 down regulation are involved. 


\section{Materials and Methods}

\section{Cell culture and 5-FU treatment}

Human breast adenocarcinoma cells MCF-7 cells were obtained from American Type Culture Collection and cultured in DMEM (Hyclone) supplemented with 10\% (v/v) heat-inactivated FBS and $1 \%(\mathrm{v} / \mathrm{v})$ penicillin-streptomycin in a $37^{\circ} \mathrm{C}$ humidified incubator with $5 \% \mathrm{CO}_{2}$ [6]. 5-FU was purchased from Sigma. 5-FU was dissolved in dimethyl sulfoxide and then divided into aliquots and stored at $-70^{\circ} \mathrm{C}$ until used. The stocks were freshly diluted in culture medium before experiment [8].

\section{Snail overexpression [25]}

MCF-7 \#5 stable cell lines (provided by Yook JI, Yonsei University) were cultured in DMEM (Hyclone) supplemented with $10 \%(\mathrm{v} / \mathrm{v})$ heat-inactivated tetracycline-free FBS (Clontech) and 1\% PS (Hyclone) and treated with 0.5 $\mu \mathrm{g} / \mathrm{ml}$ doxycycline (DOX) to induce Snail. The expression vectors pCR3.1-Snail-Flg and pCR3.1-S104, 107A Snail-Flg (provided by Yook JI, Yonsei University) were stably transfected into MCF-7 cells using jetPEI (Polyplus transfection) according to the manufacturer's instructions.

\section{Hoechst 33258 and propidium iodide $(\mathrm{HO} / \mathrm{PI})$ double staining}

To determine the cell death mode, HO (Invitrogen) and PI (Invitrogen) double staining was performed [6,8]. MCF-7 cells were seeded at a density of $2.5 \times 10^{5}$ cells $/ \mathrm{ml}$ in $35-\mathrm{mm}$ dishes. After $24 \mathrm{hr}$, the cells were treated with 5 -FU for up to $72 \mathrm{hr}$ and stained with $\mathrm{HO}(1 \mu \mathrm{g} / \mathrm{ml})$ and PI $(5 \mu \mathrm{g} / \mathrm{ml})$ for $15 \mathrm{~min}$.

\section{Western blotting}

Protein lysates obtained from cells treated with 5-FU were measured using the Bradford assay. Equal amounts of protein lysates were separated by sodium dodecyl sulfate-polyacrylamide gel electrophoresis on $12 \%$ gels, and electrotransferred to NC membrane and analyzed by Western blotting with antibodies to Akt, p-Akt, PTEN, p-PTEN, ERK1/2, p-ERK1/2 (Cell signaling), p53, PARP (Santa Cruz, CA, USA) and a-tubulin (Biogenex, CA, USA). After incubation with peroxidase-conjugated secondary antibody, protein expression was detected using ECL Western Blotting Detection Reagents (Amersham Biosciences).
Results and Discussion

Snail inhibits 5-FU-induced apoptotic cell death and switches the cell death mode to necrosis

We examined the effects of Snail on 5-FU-induced apoptosis. Previously, we showed that 5-FU caused a dose-dependent decrease in the cell viability, with a prominent effect at a concentration of $400 \mu \mathrm{M}$ [8]. After 5-FU treatment, the apoptotic morphological changes such as cell rounding and detachment and membrane blebbing were detected (Fig. 1A). HO/PI nuclear staining was performed to identify necrosis (a tumor-promoting cell death type) as well as apoptosis (a tumor-suppressive cell death type). The DNA-binding dyes $\mathrm{HO}$ is permeable to all cells (damaged or not), causing a blue fluorescence of their nuclei. In contrast, the penetration of PI is restricted to the cells with damaged membranes, turning to be red nuclear fluorescence. Thus, intact blue nuclei, condensed/fragmented blue nuclei, condensed/fragmented pink nuclei, and intact pink nuclei defined to be viable, early apoptotic, late apoptotic (secondary necrotic), and necrotic cells, respectively. When 5-FU was treated to MCF-7 cell culture for $72 \mathrm{hr}$, the typical features of apoptotic cell death namely nuclear chromatin condensation and the appearance of apoptotic bodies were observed (Fig. 1B). To examine the effects of Snail on 5-FU-induced apoptosis, we used Snail tetracycline inducible MCF-7 cells (MCF-7 \#5). When MCF-7 \#5 cells were treated with DOX to induce Snail, they exhibited EMT, the morphological change to mesenchymal cells including loss of intercellular adhesion and formation of a spindle-like cell shape and pseudopodia (Fig. 1A), with the downregulation of E-cadherin, one of the hallmarks of EMT [25]. When MCF-7 \#5 cells treated with DOX were exposed to 5-FU, their apoptotic response was significantly reduced and the necrotic response was increased, indicating that Snail switches 5-FU-induced apoptosis to necrosis (Fig. 1B). It has been recently reported that Snail confers chemoresistance of colorectal cancer cells to 5-FU [4]. Our studies show that in addition to preventing 5-FU-induced apoptosis, Snail could switch 5-FU-induced apoptosis to necrosis.

Snail induces PTEN downregulation/inactivation and Akt/PKB activation

Several prosurvival signaling pathways are involved in the acquisition of resistance against anti-cancer drugs $[1,17,21,22,24]$. The Ser/Thr kinase Akt/PKB is one of the 
A

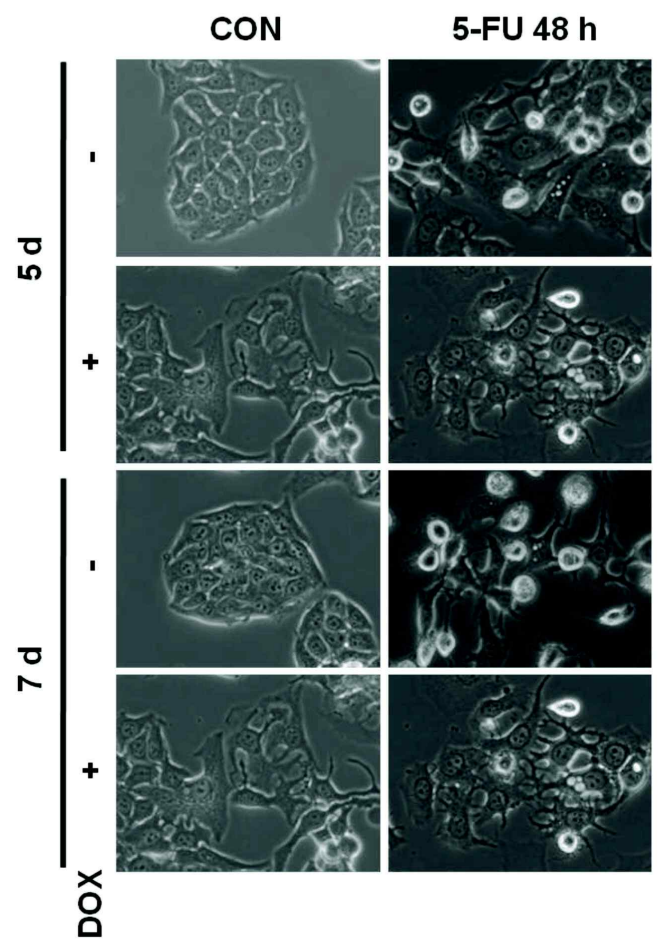

B
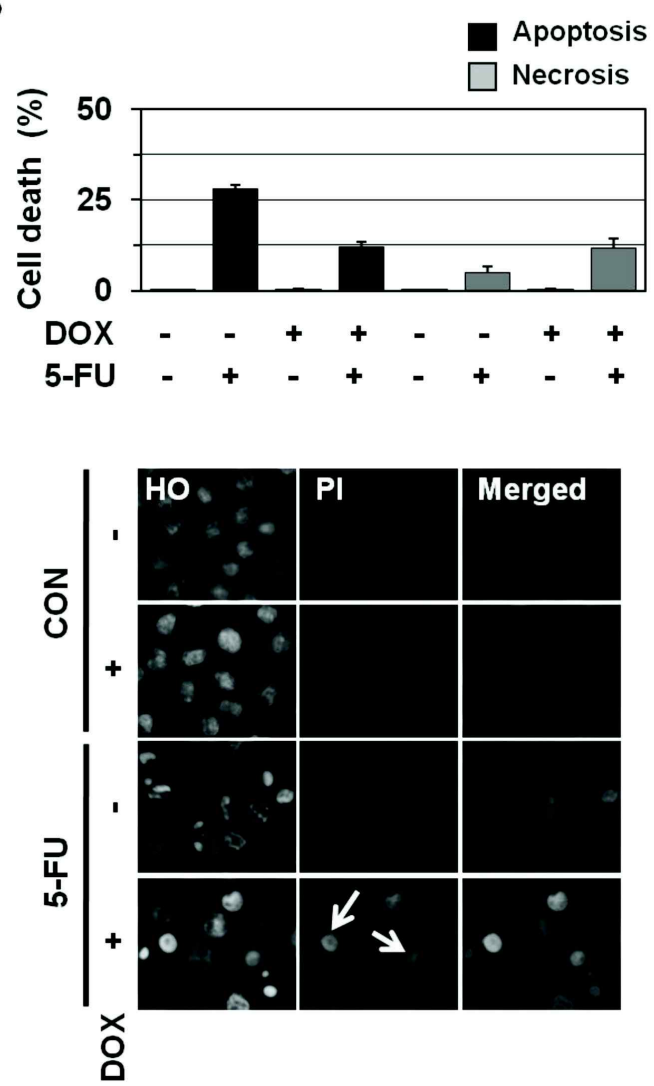

Fig. 1. Snail switches 5-FU-induced apoptotic cell death to necrosis. (A, B) MCF-7 \#5 tetracycline inducible cell line was pre-treated with $0.5 \mu \mathrm{g} / \mathrm{ml}$ DOX for the indicated times and then exposed to $400 \mu \mathrm{M} \mathrm{5-FU}$ for $48 \mathrm{~h}$ and observed under a light microscope (A). Then the cells were stained with HO/PI and observed with fluorescence microscopy (lower panel) and apoptotic and necrotic cells were scored (upper panel). Results (500-800 cells in each group) are expressed as the means \pm SEM from three independent experiments (B). Arrow, necrotic cell.

survival kinases and is frequently hyperactivated in human cancer [21,24]. It could be activated by the phosphatidylinositol 3-kinase (PI3K) pathway and inactivated by its negative regulator phosphatase PTEN. It suppresses apoptosis directly through phosphorylating $\mathrm{Bcl}-2$ or indirectly by regulating p53 and nuclear factor- $\kappa \mathrm{B}(\mathrm{NF}-\kappa \mathrm{B})$ activity. ERK1/2, a member of the mitogen-activated protein kinase (MAPK) family, also plays an essential role in drug resistance as well as tumor progression and is activated by Ras and B-Raf signaling in many human cancers [1]. ERK1/2 inhibits apoptosis by preventing p53 activity and regulating Bcl-2 family protein.

To investigate whether Snail affects the survival signal pathways, the cellular proteins were obtained from Snail-overexpressing cells and analyzed by Western blotting using antibodies to phospho-Akt and phospho-ERK1/2. As shown in Fig. 2, phosphorylation in Akt/PKB, but not
ERK1/2, proteins appeared to be increased in MCF-7 \#5 cells in which Snail was induced by DOX (Fig. 2A). We also examined the effects of ectopically overexpressed Snail on Akt/PKB activation. Transient transfection with Snail expression vectors, pCR3.1-Snail-Flg, and phosphorylation-resistant mutant Snail vectors that express more stable Snail protein, pCR3.1-S104, 107A Snail-Flg, activated Akt/PKB (Fig. 2B). Thus, Akt/PKB activation seemed to be implicated in Snail-induced cell regulation such as chemoresistance.

Then, how does Snail activate Akt/PKB? We examined if Snail-induced Akt/PKB activation is associated with inhibition of an Akt/PKB negative regulator PTEN phosphatase. We found that Snail downregulated the expression of PTEN (Fig. 2A). In aggrement of this, it has been recently shown that Snail downregulates PTEN phosphatase gene expression, resulting in Akt/PKB activation, and confers resistance to gamma radiation-induced apoptosis [2]. 
A

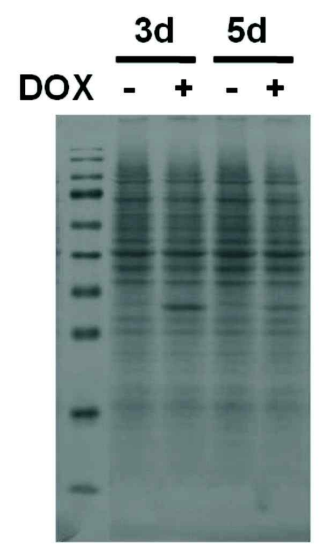

B

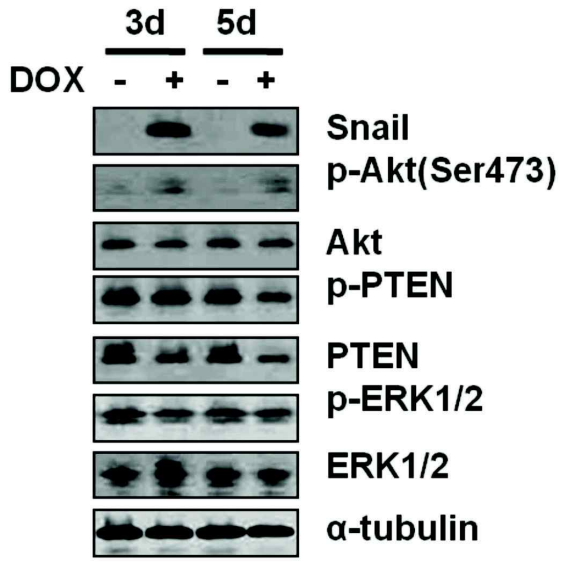

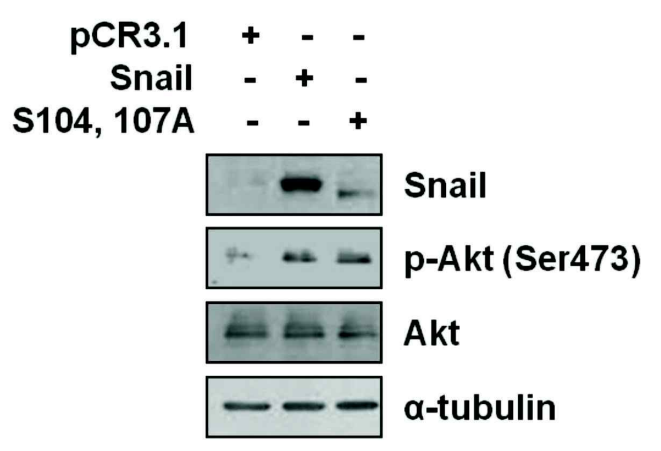

Fig. 2. Snail induces PTEN downregulation/inactivation and Akt/PKB activation. (A, B) MCF-7 \#5 cells were treated with $0.5 \mu \mathrm{g} / \mathrm{ml}$ DOX and the resulting cell lysates analyzed by SDS-PAGE and Ponceau S staining (A) and Western blotting using antibodies to Snail, p-Akt (Ser473), Akt, p-PTEN, PTEN, p-ERK1/2, ERK1/2, and a-tubulin (B). (C) MCF-7 cells were transfected with pCR3.1-wild-type Snail and S104, 107A mutant expression vector for $48 \mathrm{hr}$ and then analyzed by Western blotting using antibodies to Snail, p-Akt (Ser473), Akt, and a-tubulin.

Most cancer cells exhibit increased glycolysis for ATP production due, in part, to respiration injury (the Warburg effect). Inhibition of mitochondrial respiration has been shown to activate the NADH-Akt/PKB survival pathway [15], contributing to the acquisition of chemoresistance. Mitochondrial repression deficiency increases NADH levels and inactivates PTEN through a redox modification mechanism, resulting in Akt/PKB activation. Previously, we showed that Snail could suppress mitochondrial respiration and cytochrome $\mathrm{C}$ oxidase (COX) activity, thereby inducing a glycolytic switch [9]. As shown in Fig. 2A, Snail inhibited phosphorylation of PTEN phosphatase. Thus, we suggest that Snail may activiate Akt/PKB by inactivating PTEN activity via mitochondrial repression, in addition to downregulating PTEN gene expression.

\section{Snail downregulates p53 levels}

The tumor suppressor p53 plays a critical role(s) in 5-FU-induced apoptosis. p53 induces apoptosis by upregulating the expression of Bax, while downregulating that of Bcl-2. As shown in Fig. 3A, 5-FU induced p53, with induction of cleavage of poly(ADP-ribose) polymerase (PARP), a keynote of apoptosis [8]. Snail appeared to reduce the expression of p53 in response to 5-FU (Fig. 3A). Reduced expression of $\mathrm{p} 53$ has been implicated in the Snail-mediated resistance to apoptosis [5]. The PI3K/Akt pathway is known to activate $\mathrm{Mdm} 2$ through phosphorylation and sub- sequently inactivate p53 through the ubiquitin-proteasome system, eventually leading to inhibition of p53-dependent apoptosis $[3,10,16]$. Thus, Snail may reduce p53 levels through Akt/PKB-mediated regulation of p53 stability, in addition to directly downregulating p53 expression (Fig. 3B).

\section{Biological relevance of this study}

The present study showed that Snail switches 5-FU-induced apoptosis to necrosis, in which Akt/PKB activation and p53 downregulation are possibly involved (Fig. 3B). Mitochondrial function is important in determining the cell death mode; tumor cells with dysregulated mitochondria has been shown to undergo necrosis instead of apoptosis in response to alkylating DNA damage that induces rapid ATP depletion through PARP activation [27]. Thus, mitochondrial depression by Snail signaling pathway may alter the sensitivity of tumor cells to anticancer drugs such as 5-FU. Snail-mediated mitochondrial repression may prevent apoptosis by activating PTEN-Akt/PKB pathway and switch the cell death mode to necrosis. Necrotic cell death is characterized by the cell membrane rupture to release the cellular contents including high-mobility group box 1 protein (HMGB1) into the extracellular microenvironment [12,18,19]. It causes to promote tumor growth and angiogenesis either by increasing the probability of proto-oncogenic mutation or by a proinflammatory action of HMGB1. In contrast, apoptotic cell death is a genetically regulated process charac- 
A

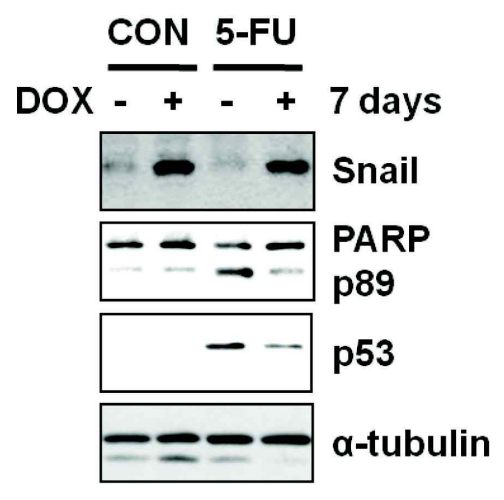

B

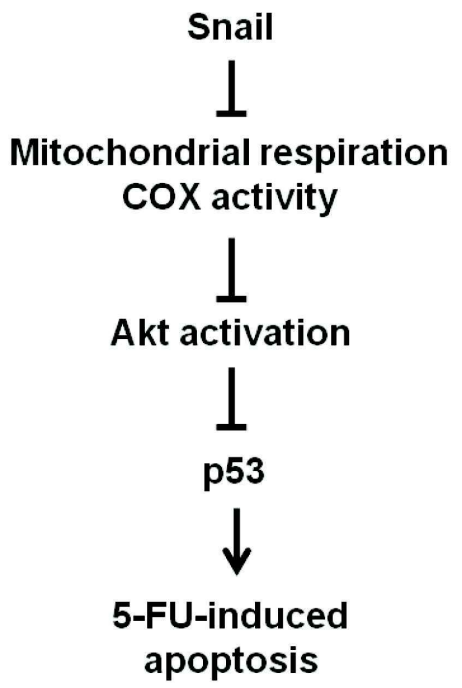

Fig. 3. (A) MCF-7 \#5 cells were treated with $0.5 \mu \mathrm{g} / \mathrm{ml}$ DOX for the indicated times and exposed to $400 \mu \mathrm{M} 5$-FU and analyzed by Western blotting using antibodies to Snail, PARP, p53, and a-tubulin. (B) A schematic representation showing a function of Snail to switch 5-FU-induced apoptosis to necrosis through Akt/PKB activation and p53 downregulation.

terized by membrane blebbing and DNA degradation and eventually, induction of apoptotic body formation. Disintegrated cell fragments are removed by phagocytes or neighboring cells, resulting in cellular deletion without inflammation. Snail expression enhances necrosis that is related with inflammation and tumorigenesis in response to 5-FU (Fig. 1B). Therefore, we suggest that Snail expression in tumor patients should be examined before 5-FU treatment to obtain the efficacy of 5-FU chemotherapy for cancer and that the strategy to prevent necrosis as an undesirable action should be delineated.

\section{Acknowledgement}

This research was supported by Essential Science Research Program through the National Research Foundation of Korea(NRF) funded by the Ministry of Education, Science and Technology (2009-0075458).

\section{References}

1. Balmanno, K. and Cook, S. J. 2009. Tumour cell survival signalling by the ERK1/2 pathway. Cell Death Differ. 16, 368-377.

2. Escriva, M., Peiro, S., Herranz, N., Villagrasa, P., Dave, N., Montserrat-Sentis, B., Murray, S. A., Franci, C., Gridley, T., Virtanen, I. and Garcia de Herreros, A. 2008. Repression of PTEN phosphatase by Snail1 transcriptional factor during gamma radiation-induced apoptosis. Mol. Cell. Biol. 28, 1528-1540.

3. Gottlieb, T. M., Leal, J. F., Seger, R., Taya, Y. and Oren, M. 2002. Cross-talk between Akt, p53 and Mdm2: possible implications for the regulation of apoptosis. Oncogene 21, 1299-1303.

4. Hoshino, H., Miyoshi, N., Nagai, K., Tomimaru, Y., Nagano, H., Sekimoto, M., Doki, Y., Mori, M. and Ishii, H. 2009. Epithelial-mesenchymal transition with expression of SNAI1-induced chemoresistance in colorectal cancer. Biochem Biophys. Res. Commun. 390, 1061-1065.

5. Kajita, M., McClinic, K. N. and Wade, P. A. 2004. Aberrant expression of the transcription factors snail and slug alters the response to genotoxic stress. Mol. Cell. Biol. 24, 7559-7566.

6. Kim, C. H., Jeon, H. M., Lee, S. Y., Ju, M. K., Moon, J. Y., Park, H. G., Yoo, M. A., Choi, B. T., Yook, J. I., Lim, S. C., Han, S. I. and Kang, H. S. 2011. Implication of snail in metabolic stress-induced necrosis. PLoS One 6, e18000.

7. Kurrey, N. K., Jalgaonkar, S. P., Joglekar, A. V., Ghanate, A. D., Chaskar, P. D., Doiphode, R. Y. and Bapat, S. A. 2009. Snail and slug mediate radioresistance and chemoresistance by antagonizing p53-mediated apoptosis and acquiring a stem-like phenotype in ovarian cancer cells. Stem Cells 27, 2059-2068.

8. Lee, S. Y., Jeong, E. K., Jeon, H. M., Kim, C. H. and Kang, H. S. 2010. Implication of necrosis-linked p53 aggregation in acquired apoptotic resistance to 5-FU in MCF-7 multicellular tumour spheroids. Oncol. Rep. 24, 73-79.

9. Lee, S. Y., Jeon, H. M., Ju, M. K., Kim, C. H., Yoon, G., Han, S. I., Park, H. G. and Kang, H. S. 2012. Wnt/snail signaling regulates cytochrome $\mathrm{c}$ oxidase and glucose 
metabolism. Cancer Res. 72, 3607-3617.

10. Levine, A. J., Feng, Z., Mak, T. W., You, H. and Jin, S. 2006. Coordination and communication between the p53 and IGF-1-AKT-TOR signal transduction pathways. Genes Dev. 20, 267-275.

11. Longley, D. B., Harkin, D. P. and Johnston, P. G. 2003. 5-fluorouracil: mechanisms of action and clinical strategies. Nat. Rev. Cancer 3, 330-338.

12. Lotze, M. T. and Tracey, K. J. 2005. High-mobility group box 1 protein (HMGB1): nuclear weapon in the immune arsenal. Nat. Rev. Immunol. 5, 331-342.

13. Nieto, M. A. 2002. The snail superfamily of zinc-finger transcription factors. Nat. Rev. Mol. Cell. Biol. 3, 155-166.

14. Peinado, H., Olmeda, D. and Cano, A. 2007. Snail, Zeb and bHLH factors in tumour progression: an alliance against the epithelial phenotype? Nat. Rev. Cancer 7, 415-428.

15. Pelicano, H., Xu, R. H., Du, M., Feng, L., Sasaki, R., Carew, J. S., Hu, Y., Ramdas, L., Hu, L., Keating, M. J., Zhang, W., Plunkett, W. and Huang, P. 2006. Mitochondrial respiration defects in cancer cells cause activation of Akt survival pathway through a redox-mediated mechanism. J. Cell Biol. 175, 913-923.

16. Qiu, W., Leibowitz, B., Zhang, L. and Yu, J. 2010. Growth factors protect intestinal stem cells from radiation-induced apoptosis by suppressing PUMA through the PI3K/ AKT/p53 axis. Oncogene 29, 1622-1632.

17. Raguz, S. and Yague, E. 2008. Resistance to chemotherapy: new treatments and novel insights into an old problem. $B r$. J. Cancer 99, 387-391.

18. Scaffidi, P., Misteli, T. and Bianchi, M. E. 2002. Release of chromatin protein HMGB1 by necrotic cells triggers inflammation. Nature 418, 191-195.

19. Vakkila, J. and Lotze, M. T. 2004. Inflammation and necrosis promote tumour growth. Nat. Rev. Immunol. 4, 641-648.

20. Vega, S., Morales, A. V., Ocana, O. H., Valdes, F., Fabregat, I. and Nieto, M. A. 2004. Snail blocks the cell cycle and confers resistance to cell death. Genes Dev. 18, 1131-1143.

21. Vivanco, I. and Sawyers, C. L. 2002. The phosphatidylinositol 3-Kinase AKT pathway in human cancer. Nat. Rev. Cancer 2, 489-501.

22. Wilson, T. R., Longley, D. B. and Johnston, P. G. 2006. Chemoresistance in solid tumours. Ann. Oncol. 17 Suppl 10, x315-324.

23. Wu, W. S., Heinrichs, S., Xu, D., Garrison, S. P., Zambetti, G. P., Adams, J. M. and Look, A. T. 2005. Slug antagonizes p53-mediated apoptosis of hematopoietic progenitors by repressing puma. Cell 123, 641-653.

24. Yamaguchi, H. and Wang, H. G. 2001. The protein kinase $\mathrm{PKB} /$ Akt regulates cell survival and apoptosis by inhibiting Bax conformational change. Oncogene 20, 7779-7786.

25. Yook, J. I., Li, X. Y., Ota, I., Hu, C., Kim, H. S., Kim, N. H., Cha, S. Y., Ryu, J. K., Choi, Y. J., Kim, J., Fearon, E. R. and Weiss, S. J. 2006. A Wnt-Axin2-GSK3beta cascade regulates Snail1 activity in breast cancer cells. Nat. Cell Biol. 8, 1398-1406.

26. Zhang, N., Yin, Y., Xu, S. J. and Chen, W. S. 2008. 5-Fluorouracil: mechanisms of resistance and reversal strategies. Molecules 13, 1551-1569.

27. Zong, W. X., Ditsworth, D., Bauer, D. E., Wang, Z. Q. and Thompson, C. B. 2004. Alkylating DNA damage stimulates a regulated form of necrotic cell death. Genes Dev. 18, 1272-1282.

\section{초록 : Snail의 AKt/PKB의 활성화와 p53의 downregulation를 통한 5-FU-induced apoptosis의 necrosis로의 전환}

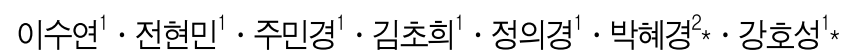

( ${ }^{1}$ 부산대학교 자연과학대학 분자생물학과, ${ }^{2}$ 부산대학교 나노바이오테크놀러지 센터)

Snail은 E-cadherin 발현을 직접 억제하는 zinc finger transcription factor로서, 암세포의 invasion과 metastasis 를 촉진시키는 epithelial-mesenchymal transition (EMT)를 유발한다. 또한 Snail은 세포사멸 자극과 세포 생존물 질의 제거로 인한 세포사멸에 대해 저항성을 나타낸다. 그러나 이에 대한 분자기작은 잘 알려져 있지 않다. 본 연구에서는 가장 널리 사용되는 항암제 중의 하나인 5-fluorouracil (5-FU)에 의한 세포사멸에 대한 Snail의 저항 성 기작에 대하여 조사하였다. MCF-7 \#5 세포주에 doxycycline (DOX)을 처리하여 Snail을 과발현시킨 세포에서 5-FU에 의한 세포사멸이 억제되고 세포괴사가 일어남을 확인하였다. DOX 처리 및 Snail expression vectors인 pCR3.1-Snail-Flg와 phosphorylation-resistant mutant Snail vector인 pCR3.1-S104, 107A Snail-Flg을 이용하여 Snail을 과발현 시킨 경우 ERK1/2의 활성에는 영향을 주지 않는 반면 PTEN 발현억제 및 불활성화, 그리고 $\mathrm{Akt} / \mathrm{PKB}$ 활성화가 유도됨을 관찰하였다. 또한, Snail은 5-FU에 의한 p53의 발현을 억제한다는 사실을 확인하였 다. 따라서 Snail은 prosurvival kinase인 Akt/PKB의 활성화와 p53 억제를 통해 5-FU에 의한 세포사멸을 세포괴 사로 전환하는 것으로 생각된다. 